\title{
Doubtful Role of IL28B Polymorphism in Occult Hepatitis B Infection
}

\author{
Marta Bes ${ }^{a, c}$ Victor Vargas ${ }^{b-d}$ Maria Piron ${ }^{a, c}$ Natalia Casamitjana ${ }^{a}$ \\ Juan Ignacio Esteban ${ }^{\text {b-d }}$ Isabel Campos-Varelab, c Lluís Puiga, c \\ Silvia Sauleda ${ }^{a, c}$

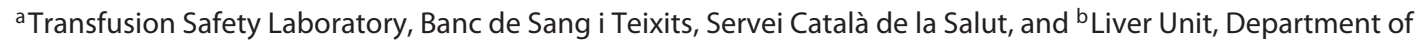 \\ Medicine, and Liver Diseases Laboratory, Institut de Recerca, Hospital Universitari Vall d'Hebron, Barcelona, \\ 'Centro de Investigación Biomédica en Red de Enfermedades Hepáticas y Digestivas del Instituto de Salud Carlos III, \\ Madrid, and ${ }^{d}$ Universitat Autònoma de Barcelona, UAB, Bellaterra, Spain
}

\section{Key Words}

Hepatitis B virus · IL28B genotype - Interferon- $\gamma$.

Interferon- $\lambda \cdot$ Occult hepatitis $B$ infection $\cdot T$-cell immune response

\begin{abstract}
Aims: To investigate the influence of IL28B polymorphism in occult hepatitis $B$ infection (OBI) and whether IL28B genetic variants are associated with hepatitis B virus (HBV)-specific T-cell responses. Patients and Methods: The rs 12979860 IL28B genotype was determined in 34 OBI blood donors, 22 spontaneous HBV resolvers, 36 inactive HBV carriers and 25 seronegative donors. T-cell responses to HBV recombinant proteins were assessed by interferon- $\gamma$ enzyme-linked immunospot assay. Results: The frequency of the IL28B CC genotype among $\mathrm{OBI}$ patients was similar to that of inactive carriers [ 41 vs. $39 \%$, respectively, $p=0.961$; odds ratio $(O R)=$ $1.10 ; 95 \%$ confidence interval $(\mathrm{Cl})=0.42-2.86 ; \mathrm{p}=0.845]$. The IL28B CC genotype was found more frequently in spontaneous resolvers, although the differences were not significant ( 45 vs. $39 \%$, spontaneous resolvers and inactive carriers, respectively; $\mathrm{p}=0.828 ; \mathrm{OR}=1.31 ; 95 \% \mathrm{Cl}=0.45-3.83 ; \mathrm{p}=$ 0.622). HBV-specific T-cell responses were detected in OBIs, and significantly stronger $\mathrm{T}$-cell responses towards hepatitis $B$ envelope antigen were observed in those with the IL28B
\end{abstract}

CC genotype. In spontaneous resolvers and inactive carriers, IL28B CC did not correlate with the magnitude of T-cell responses. Conclusions: In OBI donors, IL28B CC correlates with the intensity of HBV-specific T-cell responses. In this study, IL28BCC is not statistically associated with OBI or with $\mathrm{HBV}$ clearance, but a larger number of cases is needed before completely ruling out its role in $\mathrm{HBV}$ infection.

(c) 2015 S. Karger AG, Basel

\section{Introduction}

Hepatitis B virus (HBV) is a noncytopathic DNA virus that causes acute and chronic hepatitis [1,2]. Occult HBV infection (OBI) is characterized by the presence of $\mathrm{HBV}$ DNA in liver tissue or serum $(<200 \mathrm{IU} / \mathrm{ml})$ of individuals testing negative for hepatitis B surface antigen ( $\mathrm{HBsAg}$ ), with or without other HBV serological markers [3].

$\mathrm{HBV}$-induced liver injury and viral clearance are mediated by the host's immune responses [4]. In acute HBV infection, a cytotoxic T-lymphocyte response to $\mathrm{HBV}$ proteins is observed in patients who successfully clear the virus [4-6]. Increased hepatitis B core ( $\mathrm{HBcAg})$ - and envelope (HBeAg)-specific T-helper cell responses are also seen in patients with viral elimination [7]. In contrast, chronic $\mathrm{HBV}$ infection is characterized by an inefficient

\section{KARGER 125}

() 2015 S. Karger AG, Base

0300-5526/15/0583-0160\$39.50/0

E-Mail karger@karger.com

www.karger.com/int
Marta Bes, PhD

CIBEREHD, Transfusion Safety Laboratory

Banc de Sang i Teixits

Passeig Vall d'Hebron 119-129, ES-08035 Barcelona (Spain)

E-Mail mbes@bst.cat 
immune response to $\mathrm{HBsAg}$ and weak but demonstrable responses to polymerase, $\mathrm{HBcAg}$ and $\mathrm{HBeAg}[4,5,8]$. Recently, we observed that the HBV-specific T-cell response in individuals with occult $\mathrm{HBV}$ is comparable to the response in resolved HBV infection and has the capability to suppress viral replication to low viral loads and HBsAg expression to undetectable levels [9].

Genome-wide association studies have shown that single nucleotide polymorphisms (SNPs) within or outside the $I L 28 B$ (rs12979860) gene coding for IFN $-\lambda_{3}$ strongly associate with both spontaneous and treatmentinduced resolution of HCV infection [10-15]. Although the mechanism remains unclear, IFN- $\lambda_{3}$ inhibits viral replication, and some studies suggest that it may modulate innate and adaptive immune responses [16, 17]. Although several studies have not observed a correlation between the IL28B genotype and spontaneous clearance or resolution with pegylated interferon- $\alpha$ treatment in HBV infection [18-21], there are no studies which investigated whether the IL28B genotype could be determinant in OBI infection.

The aims of this study were to determine whether variations at the SNP rs 12979860 correlate with OBI infection in a cohort of Spanish blood donors and the extent to which rs12979860 variants correlate with the magnitude of the HBV-specific CD4+ and CD8+ T-cell response.

\section{Patients and Methods}

\section{Study Groups}

A subset of 34 OBI blood donors was enrolled for the determination of the IL28B rs12979860 genotype and the HBV-specific $\mathrm{T}$-cell immune response. OBI donors were identified during routine screening in the Blood Bank Center of Catalonia (Spain) from January 2006 to December 2008. Because liver biopsy was absent in these subjects, the definition of OBI was adapted and established as HBsAg-negative, anti-HBc-positive (anti-HBc IgM-negative) and anti-HBs-positive or -negative testing, with HBV DNA $<200 \mathrm{IU} / \mathrm{ml}$ in serum [3]. The comparison populations were 22 donors with spontaneously resolved $\mathrm{HBV}, 36$ inactive HBV carriers and $25 \mathrm{HBV}$-seronegative donors. The characteristics of the study subjects are shown in table 1 . The study was approved by the Institutional Review Board on Clinical Research. None of the donors included in the study presented a coinfection with $\mathrm{HCV}$ and/or HIV.

\section{Serological Tests}

All blood donations were tested individually for HBV DNA by the transcription-mediated amplification system (Procleix Ultrio Assay, Novartis, Emeryville, Calif., USA; detection limit $10 \mathrm{IU} / \mathrm{ml}$; positive hit rate $95 \%)$. Specimens initially reactive were confirmed by HBV DNA proteinase K extraction and real-time PCR according to a previously published protocol [22].

IL28B Genotype and Occult Hepatitis B Infection
Donations were screened for HBsAg with a commercial chemiluminescent immunoassay (Prism, Abbott Diagnostics, Wiesbaden, Germany). In samples confirmed to be reactive to HBsAg and/or HBV DNA, antibodies to core (total anti-HBc, anti-HBc IgM) and anti-HBs were determined (Architect, Abbott Diagnostics).

In HBV DNA-positive donations, the HBV genotype was determined using a commercial line probe assay (INNO-LIPA HBV Kit, Innogenetics, Belgium).

\section{IL28B Genotyping}

DNA was extracted from $5-10 \times 10^{6}$ peripheral blood mononuclear cells (PBMCs) using a QIAamp DNA Blood Minikit (Qiagen, Hilden, Germany). IL28B rs12979860 genotyping was performed using real-time PCR based on TaqMan technology (Applied Biosystems, Foster City, Calif., USA) [23]. The primers used were $5^{\prime}$-GCCTGTCGTGTACTGAACCA-3' (forward) and $5^{\prime}$-GCGCGGAGTGCAATTCAAC- $3^{\prime}$ (reverse), and the TaqMan MGB probe sequences were $5^{\prime}$-TGGTTCGCGCCTTC- $3^{\prime}$ and $5^{\prime}$-CTGGTTCACGCCTTC-3'. The probes were labeled with fluorescent dyes VIC and FAM, respectively. PCR was carried out in a total of $25 \mu \mathrm{l}$, and the thermal cycling profile was as follows: incubation for $2 \mathrm{~min}$ at $50^{\circ}$, followed by a denaturation step at $95^{\circ}$ for $10 \mathrm{~min}$, and $40 \mathrm{cycles}$ at $95^{\circ}$ for $1 \mathrm{~min}, 60^{\circ}$ for $1 \mathrm{~min}$. Genotyping of each sample was analyzed by the SDS software (Applied Biosystems).

\section{HBV Antigens}

Purified recombinant $\mathrm{HBV}$ antigens (HBsAg A2 genotype, $\mathrm{HBcAg}$ and $\mathrm{HBeAg}$ ) were purchased from Prospec (Rehovot, Israel). Recombinant HBsAg A2 was expressed in the yeast Pichia pastoris, and $\mathrm{HBcAg}$ and $\mathrm{HBeAg}$ were expressed in Escherichia coli and used at $2 \mu \mathrm{g} / \mathrm{ml}$ as previously described [15]. Antigen purity was $>95 \%$ for $\mathrm{HBsAg} \mathrm{A} 2$ and $\mathrm{HBeAg}$, and $>90 \%$ for $\mathrm{HBcAg}$.

\section{Interferon- $\gamma$ Enzyme-Linked Immunospot Assay}

Cryopreserved PBMCs were used in all studies. Duplicates of thawed PBMCs were tested by IFN- $\gamma$ enzyme-linked immunospot (ELISpot) assay as previously reported [15]. Results were expressed as number of IFN- $\gamma$ spot-forming cells (SFCs) per $10^{6}$ PBMCs. Assays with high background (mean 10 SFCs/well in buffer control wells) or no phytohemagglutinin responses were excluded.

\section{Statistical Analysis}

Fisher's exact test or $\chi^{2}$ and Student's $t$ tests were used for statistical comparison of rates and of means of normally distributed quantitative measures, respectively. Results are expressed as odds ratios (ORs) with 95\% confidence intervals (CIs) [24]. Medians of IFN- $\gamma$ SFCs among groups were compared with a nonparametric Mann-Whitney $U$ test. $p$ values of less than 0.05 were considered significant. All calculations were performed with SPSS software 15.0 (SPSS Inc., Chicago, Ill., USA).

\section{Results}

The frequency of the CC genotype at the SNP rs12979860 among OBI blood donors was similar to that of inactive HBV carriers (41 vs. $39 \%$, respectively, $\mathrm{p}=$ 
Table 1. Baseline characteristics and IL28B rs12979860 genotype in the study population according to HBV infection outcome

\begin{tabular}{|c|c|c|c|c|}
\hline & OBI & $\begin{array}{l}\text { Spontaneous } \\
\text { resolvers }\end{array}$ & $\begin{array}{l}\text { Inactive HBV } \\
\text { carriers }\end{array}$ & Seronegative \\
\hline Number & 34 & 22 & 36 & 25 \\
\hline Mean age $\pm S D$, years & $56 \pm 8$ & $54 \pm 9$ & $42 \pm 11^{*}$ & $46 \pm 10^{*}$ \\
\hline Gender, males & $25(74)$ & $15(68)$ & $21(58)$ & $14(56)$ \\
\hline European ancestry, $\mathrm{n}$ & $34(100)$ & $19(86)$ & $30(83)$ & $25(100)$ \\
\hline \multicolumn{5}{|l|}{$\mathrm{ALT}, \mathrm{IU} / \mathrm{l}$} \\
\hline Median & 20 & n.d. & 17 & n.d. \\
\hline Range & $10-55$ & n.d. & $10-47$ & n.d. \\
\hline HBsAg & neg. & neg. & pos. & neg. \\
\hline HBV DNA, IU/ml & $<200$ & und. & $<10^{4}$ & und. \\
\hline Anti-HBc & pos. & pos. & pos. & neg. \\
\hline Anti-HBs $>10 \mathrm{IU} / \mathrm{l}^{\mathrm{a}}$ & $17(50)$ & $22(100)$ & & \\
\hline \multicolumn{5}{|c|}{ Subjects infected with HBV genotype ${ }^{\mathrm{b}}, \mathrm{n}$} \\
\hline A & 1 & & 8 & \\
\hline $\mathrm{D}$ & 8 & & 20 & \\
\hline $\mathrm{E}$ & & & 3 & \\
\hline $\mathrm{F}$ & 1 & & 1 & \\
\hline $\mathrm{G}$ & 1 & & 1 & \\
\hline $\mathrm{H}$ & 1 & & & \\
\hline Mixed HBV genotypes & 1 & & 3 & \\
\hline \multicolumn{5}{|l|}{ IL28B rs12979860 SNP, $\mathrm{n}$} \\
\hline $\mathrm{CC}$ & $14(41)$ & $10(45)$ & $14(39)$ & $9(36)$ \\
\hline Non-CC (CT + TT) & $20(59)$ & $12(55)$ & $22(61)$ & $16(64)$ \\
\hline
\end{tabular}

Figures in parentheses indicate percentages. ALT $=$ Alanine aminotransferase; $n . d .=$ not determined; neg. $=$ negative; pos. $=$ positive; und. $=$ undetectable, i.e. $<10 \mathrm{IU} / \mathrm{ml} .{ }^{*} \mathrm{p}<0.001$ : significant differences between OBI, inactive carriers and HBV seronegative blood donors.

a Detection limit: $0.1 \mathrm{IU} / \mathrm{l}$.

${ }^{\mathrm{b}} \mathrm{HBV}$ genotype could only be determined by hybridizing in 13 subjects in the OBI group.

$0.961 ; \mathrm{OR}=1.10 ; 95 \% \mathrm{CI}=0.42-2.86 ; \mathrm{p}=0.845)$. Similarly, the IL28B CC genotype was found more frequently in donors who spontaneously resolved HBV infection, although the differences were not significant ( 45 vs. $39 \%$, spontaneous resolvers and inactive carriers, respectively, $\mathrm{p}=0.828 ; \mathrm{OR}=1.31 ; 95 \% \mathrm{CI}=0.45-3.83 ; \mathrm{p}=0.622$ ).

To determine the intensity of the HBV immune response, we determined the median number of SFCs to different $\mathrm{HBV}$ antigens and compared them between study groups. The median IFN- $\gamma$ SFCs $/ 10^{6}$ PBMCs for HBsAg was 300 in the OBI group, a value higher than that seen in inactive carriers (300 vs. $140, \mathrm{p}=0.011$ ). For $\mathrm{HBcAg}$, OBI donors presented a median of $285 \mathrm{IFN}-\gamma$ SFCs $/ 10^{6}$ PBMCs; again, this was higher than that of inactive carriers ( 285 vs. $135, \mathrm{p}=0.021$ ). The same profile was observed for HBeAg (210 OBI vs. 95 inactive carriers, $\mathrm{p}=$ $0.003)$. The magnitude of the IFN- $\gamma$ response to the 3 $\mathrm{HBV}$ antigens used in the ELISpot test did not differ be- tween the OBI patients and donors with spontaneously resolved infection ( 300 vs. $530, \mathrm{p}=0.174$, for HBsAg; 295 vs. $195, \mathrm{p}=0.298$, for $\mathrm{HBcAg}$ and 210 vs. $120, \mathrm{p}=0.190$, for $\mathrm{HBeAg}$, respectively).

To determine whether IL28B genetic variation influences HBV-specific T-cell responses in blood donors with different HBV status, we stratified each study group according to the rs12979860 genotype (CC vs. non-CC). As shown in figure 1, in spontaneous resolvers and inactive HBV carrier groups, the presence of the IL28B CC genotype did not correlate with the quality (HBV antigen) or magnitude of T-cell responses (number of SFCs; fig. 1). In blood donors with spontaneous HBV clearance, the median number of IFN- $\gamma$ SFCs per $10^{6}$ PBMCs in those with the IL28B CC genotype was similar to that observed in those with the non-CC genotype for all studied antigens (395 vs. 715 for HBsAg, 195 vs. 220 for $\mathrm{HBcAg}$ and 120 vs. 150 for HBeAg, in IL28B CC and 


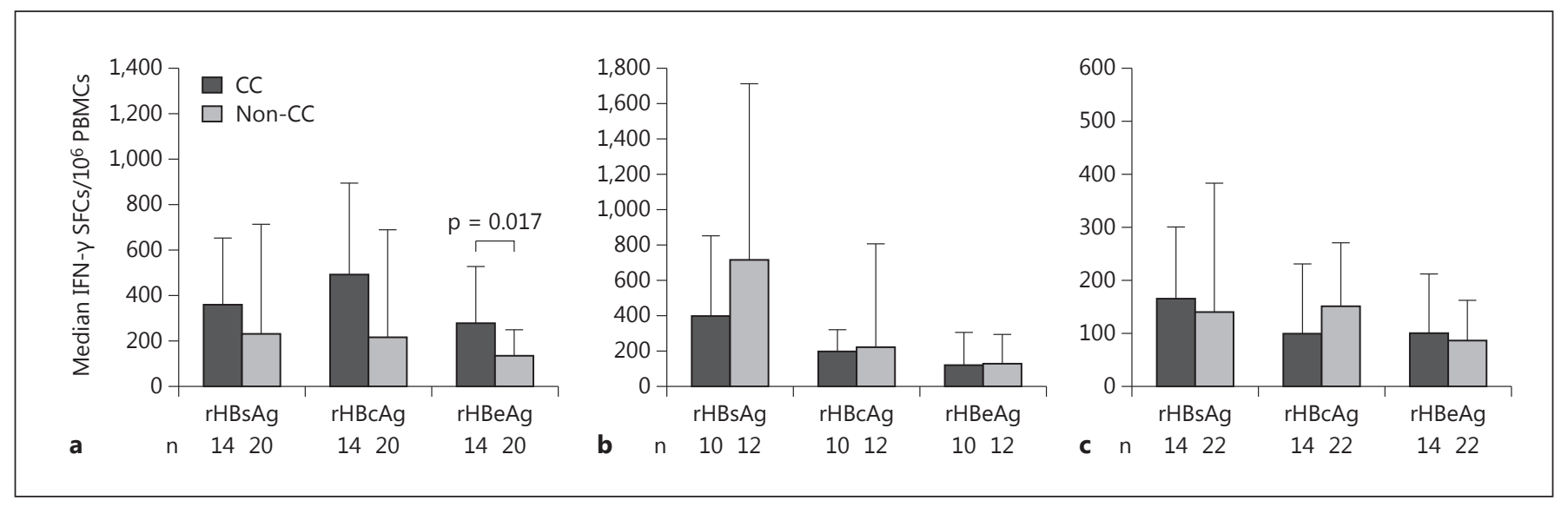

Fig. 1. Ex vivo IFN- $\gamma$ ELISpot responses to HBV antigens in each study group according to IL28B genotype. The results are expressed as medians of IFN- $\gamma$ SFC/ $10^{6}$ PBMCs. Medians among IL28B genetic variants (IL28B CC and IL28B non-CC genotypes) were compared with the Mann-Whitney U test. a OBI. b Spontaneous resolvers. c Inactive HBV carriers.

IL28B non-CC genotypes, respectively; $\mathrm{p}=$ not significant). Similar findings were seen in inactive $\mathrm{HBV}$ carriers (165 vs. 140 for HBsAg, 100 vs. 150 for HBcAg and 100 vs. 85 for HBeAg, IL28B CC and IL28B non-CC, respectively; $\mathrm{p}=$ not significant; fig. 1 ). Surprisingly in the OBI group, donors with the IL28B CC genotype presented an intensity of IFN $-\gamma$ responses higher than blood donors with the IL28B non-CC genotype, although the differences were only significant concerning the envelope antigen (360 vs. 230 for HBsAg, 495 vs. 215 for HBcAg and 280 vs. 135 for HBeAg, IL28B CC and IL28B non-CC, respectively; fig. 1). The same results were observed when we only considered European blood donors (data not shown).

\section{Discussion}

Genome-wide association studies identified several SNPs close to/within the IL28B gene, strongly associated with both spontaneous and IFN- $\alpha$-treatmentinduced HCV clearance [10-15]. IL28B $\left(\right.$ IFN- $\left.\lambda_{3}\right)$ triggers a cascade through the JAK-STAT pathway that upregulates the IFN-stimulated genes (ISGs). The effects of IL28B are similar to those of type I IFNs (IFN- $\alpha$ and IFN- $\beta$ ); however, IFN $-\lambda_{3}$ binds to a distinct receptor that may modulate a different set of ISGs [25]. Because IFN- $\alpha$ and ISGs are thought to be important in the immune response to $\mathrm{HBV}[26,27]$, we can assume that IL28B may also be important in spontaneous $\mathrm{HBV}$ clearance and in OBI. A recent study performed in a large Chinese cohort has shown that the IL28B rs12979860 polymorphism was not significantly associated with spontaneous HBV recovery, liver cirrhosis, clearance of HBeAg and HBV DNA levels [28]. However, there are no studies that have investigated whether the IL $28 B$ genotype could be determinant in OBI. In our study among Spanish blood donors, we have found that the IL28B CC genotype was not significantly different neither between OBI and inactive carriers (41 vs. $39 \%$ rs $12979860 \mathrm{CC}$, respectively, $\mathrm{p}=0.961 ; \mathrm{OR}=1.10$ ) nor between spontaneous HBV recovery and inactive carriers (45 vs. $39 \%$ rs 12979860 CC, respectively, $\mathrm{p}=$ $0.828 ; \mathrm{OR}=1.31)$. However, the frequency of $I L-28 B \mathrm{CC}$ was lower in inactive carriers, therefore a large number of individuals should be studied in order to completely rule out any possible association between $I L-28 B$ polymorphisms and HBV infection outcome.

It is not known how rs1298860 affects the function of IL28B, but presumably it alters the immune function towards HCV but not HBV. We also consider that, in addition to inducing ISG expression, IL28B may activate alternative antiviral pathways, such as the adaptive immune response, which may be more important in $\mathrm{HCV}$. This is supported by a study in which IFN- $\lambda_{3}$, when used as a vaccine adjuvant, significantly increased peripheral blood CD8+ T cells and led to an increase in antigenspecific perforin induction and degranulation [29]. However, in previous studies, we demonstrated that OBI blood donors showed HBV-specific T-cell respons- 
es which have the capability to suppress the viral replication to low viral loads and HBsAg expression to undetectable levels [9]. In this regard, the findings of the present study that a stronger T-cell response towards HBV antigens, especially $\mathrm{HBeAg}$, was more evident among OBI donors with the CC rs12979860 genotype are intriguing. Although these findings have to be interpreted with caution because of the limited number of individuals, this might suggest that although the IL28B CC genotype is not clearly associated with HBV resolution, it could be determinant to induce more efficient adaptive immune responses in HBV, especially in those patients with OBI.

\section{Acknowledgments}

This work has been supported by grants: PI10/01505 from the Spanish Ministry of Health and a research grant from the Fundació Privada Catalana de l'Hemofilia. CIBEREHD is funded by the Instituto de Salud Carlos III (Madrid, Spain).

\section{References}

1 Shi YH, Shi $\mathrm{CH}$ : Molecular characteristics and stages of chronic hepatitis B virus infection. World J Gastroenterol 2009;15:30993105.

- 2 Baumert TF, Thimme R, Weizsäcker FV: Pathogenesis of hepatitis B virus infection. World J Gastroenterol 2007;13:82-90.

3 Raimondo G, Allain JP, Brunetto MR, Buendia MA, Chen DS, Colombo M, Craxì A, Donato F, Ferrari C, Gaeta GB, Gerlich WH, Levrero M, Locarnini S, Michalak T, Mondelli MU, Pawlotsky JM, Pollicino T, Prati D, Puoti M, Samuel D, Shouval D, Smedile A, Squadrito G, Trépo C, Villa E, Will H, Zanetti AR, Zoulim F: Statements from the Taormina expert meeting on occult hepatitis B virus infection. J Hepatol 2008;49:652-657.

4 Liaw YF, Chu CM: Hepatitis B virus infection. Lancet 2009;373:582-592.

5 Chisari FV: Cytotoxic T cells and viral hepatitis. J Clin Invest 1997;99:1472-1477.

-6 Thimme R, Wieland S, Steiger C, Ghrayeb J, Reimann KA, Purcell RH, Chisari FV: CD8(+) $\mathrm{T}$ cells mediate viral clearance and disease pathogenesis during acute hepatitis B virus infection. J Virol 2003;77:68-76.

-7 Ferrari C, Bertoletti A, Penna A, Cavalli A, Valli A, Missale G, Pilli M, Fowler P, Giuberti $\mathrm{T}$, Chisari FV: Identification of immunodominant $\mathrm{T}$ cell epitopes of the hepatitis $\mathrm{B}$ virus nucleocapsid antigen. J Clin Invest 1991; $88: 214-222$

8 Löhr HF, Weber W, Schlaak, Goergen B, Meyer zum Buschenfelde KH, Gerken G: Proliferative response of CD4(+) T cells and hepatitis $B$ virus clearance in chronic hepatitis with or without hepatitis B e-minus hepatitis B virus mutants. Hepatology 1995;22:61-68.

-9 Bes M, Vargas V, Piron M, Casamitjana N, Esteban JI, Vilanova N, Pinacho A, Quer J, Puig L, Guardia J, Sauleda S: T cell responses and viral variability in blood donation candidates with occult hepatitis B infection. J Hepatol 2012;56:764-774.

10 Thomas DL, Thio CL, Martin MP, Qi Y, Ge D, O'Huigin C, Kidd J, Kidd K, Khakoo SI, Alexander G, Goedert JJ, Kirk GD, Donfield
SM, Rosen HR, Tobler LH, Busch MP, McHutchison JG, Goldstein DB, Carrington M: Genetic variation in IL28B and spontaneous clearance of hepatitis C virus. Nature 2009;461:798-802.

11 Ge D, Fellay J, Thompson AJ, Simon JS, Shianna KV, Urban TJ, Heinzen EL, Qiu P, Bertelsen AH, Muir AJ, Sulkowski M, McHutchison JG, Goldstein DB: Genetic variation in IL28B predicts hepatitis C treatment-induced viral clearance. Nature 2009;461:399401.

12 Rauch A, Kutalik Z, Descombes P, Cai T, Di Iulio J, Mueller T, Bochud M, Battegay M, Bernasconi E, Borovicka J, Colombo S, Cerny A, Dufour JF, Furrer H, Günthard HF, Heim M, Hirschel B, Malinverni R, Moradpour D, Müllhaupt B, Witteck A, Beckmann JS, Berg T, Bergmann S, Negro F, Telenti A, Bochud PY: Genetic variation in IL28B is associated with chronic hepatitis C and treatment failure: a genome-wide association study. Gastroenterology 2010;138: 1338-1345.

13 Suppiah V, Moldovan M, Ahlenstiel G, Berg T, Weltman M, Abate ML, Bassendine M, Spengler U, Dore GJ, Powell E, Riordan S, Sheridan D, Smedile A, Fragomeli V, Müller T, Bahlo M, Stewart GJ, Booth DR, George J: IL28B is associated with response to chronic hepatitis $C$ interferon- $\alpha$ and ribavirin therapy. Nat Genet 2009;41:1100-1104.

14 Balagopal A, Thomas DL, Thio CL: IL28B and the control of hepatitis $C$ virus infection. Gastroenterology 2010;139:1865-1876.

15 Bes M, Sauleda S, Campos-Varela I, Rodriguez-Frias F, Casamitjana N, Homs M, Piron M, Quer J, Tabernero D, Guardia J, Puig L, Esteban JI: IL28B genetic variation and hepatitis $\mathrm{C}$ virus-specific CD4+ $\mathrm{T}$-cell responses in anti-HCV-positive blood donors. J Viral Hepat 2012;19:867-871.

16 Honda M, Sakai A, Yamashita T, Nakamoto Y, Mizukoshi E, Sakai Y, Yamashita T, Nakamura M, Shirasaki T, Horimoto K, Tanaka Y, Tokunaga K, Mizokami M, Kaneko S: Hepatic ISG expression is associated with genetic variation in interleukin $28 \mathrm{~B}$ and outcome of IFN therapy for chronic hepatitis C. Gastroenterology 2010;139:499-509.

17 Li M, Liu X, Zhou Y, Shao BS: Interferon- $\lambda$ s: the modulators of antivirus, antitumor, and immune responses. J Leuk Biol 2009;86:2332.

18 Martin MP, Qi Y, Goedert JJ, Hussain SK, Kirk GD, Hoots WK, Buchbinder S, Carrington $\mathrm{M}$, Thio CL: IL28B polymorphism does not determine outcome of hepatitis $\mathrm{B}$ virus or HIV infection. J Infect Dis 2010;202: 1749-1753.

19 Sonneveld MJ, Wong V, Woltman AM, Wong GL, Cakaloglu Y, Zeuzem S, Buster EH, Uitterlinden AG, Hansen BE, Chan HL, Janssen HL: Polymorphisms near IL28B and serologic response to peginterferon in $\mathrm{HBeAg}$ positive patients with chronic hepatitis $\mathrm{B}$. Gastroenterology 2012;142:513-520.

20 Lampertico P, Viano M, Cheroni C, Facchetti F, Invernizzi F, Valveri V, Soffredini R, Abrignani S, De Francesco R, Colombo M: IL28B polymorphisms predict interferon-related hepatitis B surface antigen seroclearance in genotype $\mathrm{D}$ hepatitis $\mathrm{B}$ e antigen-negative patients with chronic hepatitis B. Hepatology 2013;57:890-896.

21 Holmes JA, Nguyen T, Ratnam D, Heerasing NM, Tehan JV, Bonanzinga S, Dev A, Bell S, Pianko S, Chen R, Visvanathan K, Hammond R, Iser D, Rusli F, Sievert W, Desmond PV, Bowden DS, Thompson AJ: IL28B genotype is not useful for predicting treatment outcome in Asian chronic hepatitis B patients treated with pegylated interferon- $\alpha$. J Gastroenterol Hepatol 2013;28:861-866.

22 Roth WK, Weber M, Petersen D, Drosten C, Buhr S, Sireis W, Weichert W, Hedges D, Seifried E: NAT for HBV and anti-HBc testing increase blood safety. Transfusion 2002;42: 869-875.

23 Montes-Cano MA, Garcia-Lozano JR, Abad-Molina C, et al: Interleukin-28b genetic variants and hepatitis virus infection by different viral genotypes. Hepatology 2010;52:33-37. 
24 Domenech JM, Granero R: MacroICI2IP for SPSS Statistics. Confidence intervals for measures of association: $2 \times 2$ table (independence samples) (computer program). V2008.02.29. Bellaterra, Universitat Autònoma de Barcelona, 2008. http://www.metodo.uab.cat/macros.htm.

25 Kim SU, Song KJ, Chang HY, Shin EC, Park JY, Kim do Y, Han KH, Chon CY, Ahn SH: Association between IL28B polymorphisms and spontaneous clearance of hepatitis B virus infection. PLoS One 2013;8:e69166.

26 Guidotti LG, Morris A, Mendez H, Koch R, Silverman RH, Williams BR, Chisari FV: Interferon-regulated pathways that control hepatitis $B$ virus replication in transgenic mice. Virol 2002;76:2617-2621.

7 Robek MD, Boyd BS, Chisari FV: Lambda interferon inhibits hepatitis $B$ and $C$ virus replication. J Virol 2005;79:3851-3854.
28 Peng LJ, Guo JS, Zhang Z, Shi H, Wang J, Wang JY: IL28B rs12979860 polymorphism does not influence outcomes of hepatitis B virus infection. Tissue Antigens 2012;79:302305

29 Morrow MP, Pankhong P, Laddy DJ, Schoenly KA, Yan J, Cisper N, Weiner DB: Comparative ability of IL-12 and IL-28B to regulate $\mathrm{T}_{\text {reg }}$ populations and enhance adaptive cellular immunity. Blood 2009;113:5868-5877. 